haastaa. Ja juuri näistä kumpuaa lohdullisuus, ortodoksisuudelle niin merkittävän perinteen sinnikkyys, päättymätön jatkuvuus.

Karina Lukin

\title{
Elämä on toisaalla
}

\section{Anne Lounsbery: Life is Elsewhere. Sym- bolic Geography in the Russian Provinces, 1800-1917. Ithaca and London: Northern Illinois University Press. 344 s. ISBN 978-1- 5017-4791-5.}

Venäläisen kirjallisuuden tutkimus on pitkään keskittynyt Pietariin ja Moskovaan sekä näiden väliseen dikotomiseen asetelmaan. Tämän lisäksi huomiota on kiinnitetty imperiumin rajaseutuihin, kun taas keskusten ja rajojen väliin jäävät laajat alueet ovat jääneet vähemmälle huomiolle. Ne kuitenkin muodostavat 1800-luvun kirjallisuudessa aivan keskeisen semanttisen vyöhykkeen: provinssin ja erityisesti provinssikaupungin. Näin kirjoittaa New Yorkin yliopistossa venäläistä kirjallisuutta opettava Anne Lounsbery oivaltavassa monografiassaan Life is Elsewhere. Symbolic Geography in the Russian Provinces, 1800-1917.

Viime vuosina venäläinen provinssi on tuntunut enenevässä määrin kiinnostavan kulttuurintutkijoita. Esimerkiksi Lyudmila Partsin monografia In Search of the True Russia - The Provinces in Contemporary Nationalist Discourse (2018) syventyy provinssin merkityksiin nykykulttuurissa (muutaman viime vuosikymmenen mediaan, kirjallisuuteen ja televisioon). Vaikka Lounsbery tutkiikin teoksessaan 1800-luvun klassista kaanonia, hänen teoksessaan provinssin merkitykset aukeavat osin varsin samalla tavoin kuin Partsilla. Venäjänkielisessä kirjallisuudentutkimuksessa provinssi on ollut jo pitempään tutkimuksen kohteena, mistä esimerkkinä toimii Lounsberynkin lähteistä löytyvä, tutkimuksessa usein käytetty A. F. Belousovin, T. V. Tsivjanin ja V. N. Sažinin toimittama kokoomateos Russkaja provintsija: mif-tekst-realnost (2000).

Lounsberyn lähtökohtana on kulttuurisemiotiikasta tuttu ajatus siitä, että Venäjällä keskuksen ja periferian välinen vastakkainasettelu on aivan erityisen korostunut. Keskus (Moskova, Pietari) on merkityksillä ladattu, kun taas periferia näyttäytyy keskuksen toiseutena, vähämerkityksisempänä kenttänä. Tämä näkyy Lounsberyn mukaan erityisesti venäläisessä korkeakirjallisessa proosassa, jossa Venäjän kä- sittäminen on varsinkin realismin aikana tavattu sitoa pääkaupunkien tarjoamaan perspektiiviin. Näin pääkaupunki yhdistyy toimijuuteen, kun taas provinssi näyttäytyy tarkastelun kohteena, objektina. Vasta-argumenttina voitaisiin tosin esittää, että jos keskus ymmärretään pisteenä, jossa merkitys on latautunein, saattaisi 1800-luvun venäläisen kirjallisuuden keskukseksi julistaa nimenomaan nimettömän $\mathrm{N}: \mathrm{n}$ pikkukaupungin $(\operatorname{gorod} N)$. Kuten Lounsbery osoittaa, viimeistään Gogolista lähtien ja aina Tšehoviin ja Sologubiin saakka kaunokirjallisuuden kuvittelema provinssikaupunki on: 1) tyhjä, 2) kuollut, 3) anonyymi, 4) epäautenttinen, 5) jälkeenjäänyt, 6) banaali, 7) enemmän tai vähemmän barbaarinen ja 8) muutenkin kaikkea mitä Moskova ja varsinkaan Pariisi ei ole. Provinssin merkitys määrittyy siis negatiivisesti ja toiseutena mutta symboliikan vähyydestä sitä ei voi syyttää. Niinpä suuri osa 1800 -luvun proosaa käsittelee muodossa tai toisessa kaipuuta Pietariin tai Moskovaan - joskaan, kuten Lounsbery tarkkanäköisesti huomauttaa, ei ole lainkaan selvää, että nämä tarjoaisivat ratkaisun pikkukaupunkilaisuuden syndroomaan, sillä ne itsekin saattavat osoittautua provinsiaalisiksi suhteessa imitoimaansa Eurooppaan. Tässä Lounsbery tulee käsittelyssään lähelle Lyudmila Partsin näkökulmia, joissa provinssi vs. pääkaupunki -dikotomia on korvattu kolmikantaisella mallilla provinssi - Moskova - "Länsi".

Yksi Lounsberyn keskeisistä argumenteista koskee juuri venäläisen pikkukaupungin anonyymiutta ja tämän seikan suhdetta keskuksen ja periferian väliseen oppositioon. Hän esittää osuvien vertailujen avulla, että siinä missä venäläisessä 1800-luvun kirjallisuudessa pikkukaupunkia harvemmin nimetään, vaan sen tarkoitus on olla "mikä hyvänsä kaupunki" pääkaupunkien ulkopuolella, eurooppalaisessa ja yhdysvaltalaisessa kirjallisuudessa tilanne on toinen. Usein jopa nimettömien provinssikaupunkien kuningattareksi nostetulla Gustave Flaubertin Rouva Bovaryn pikkukaupungilla on tosiasiassa nimi ja varsin tarkka sijainti Normandiassa, puhumattakaan paikallisväriä kerronnassa viljelevästä alueellisesta kirjalli- 
suudesta. Tämän Lounsbery näkee yhdistyvän siihen, että esimerkiksi juuri Ranskassa on Pariisin epäämättömästä keskeisyydestä huolimatta vähemmän vastakkainasettelua keskuksen ja periferian välillä, koska monilla seuduilla on oma vahva kulttuurinen keskuksensa. Venäjän kontekstissa taas nimeämättömyys ja mikätahansisuus heijastaa pääkaupunkien ja provinssin välistä vastakkainasettelua: pikkukaupungeilla ei ole niitä toisistaan erottavia ominaispiirteitä vaan eronteko tapahtuu nimenomaan suhteessa keskukseen. Laajempikin pohdinta aiheesta, miten Venäjän provinssin ja pääkaupunkien välinen suhde eroaa maaseudun ja kaupungin välisestä dikotomiasta, joka on varsin universaali teema eri kielillä kirjoitetussa kirjallisuudessa, olisi tässä kohtaa ollut kiinnostavaa.

Tilanne muuttuu modernismin aikana 1900-luvun alkupuolella, kun myös kaunokirjallisuudessa näkyy kasvava kiinnostus alueellisiin kulttuureihin: esimerkiksi Leonid Dobytšinin tuotannossa kuten romaanissa Gorod En nimeämätön kaupunki saa vahvan omaleimaisia, Daugavpilsiksi tunnistettavia kulttuurisia piirteitä, jotka ovat olennainen osa kuvatun kaupungin provinsiaalisuutta. Myös tämän muutoksen Lounsbery huomioi teoksensa kokoavassa luvussa, joskin juuri Dobytšinin, ehkä keskeisimmän pikkukaupunkimodernistin, monisyinen problematiikka jää häneltä harmillisesti tarkastelematta.

Lounsberyn tarkastelu kattaa koko pitkän 1800-luvun lähtien liikkeelle Puškinista provinsiaalisuuden kysymyksiä enteilevänä kirjailijana ja muun muassa Herzenistä provinssien takapajuisuuden paaluttajana. Käsittely kattaa vuosisadan klassikot provinssikirjallisuuden suurnimistä Gogolista ja Tšehovista harvemmin tässä yhteydessä käsiteltyihin Turgeneviin, Tolstoihin ja Dostojevskiin mutta pureutuu vähemmän tunnettuihinkin nimiin ja ilahdut- tavasti myös naiskirjailijoihin. 1800-luvun provinsiaalisista naiskirjailijoista Lounsbery nostaa esimerkeiksi osittain samoja nimiä kuin Irina Savkina teoksessaan Provintsialki russkoi literatury (ženskaja proza 30- $i$ 40-h godov XIX veka (1998). Savkinaan viitaten Lounsbery näkee 1830-40-luvuilla venäläiseen kirjallisuuteen astuneiden naiskirjailijoiden olevan kaksinkertaisesti marginaalissa: miesten hallitsemassa, pääkaupunkikeskeisessä kirjallisuusmaailmassa provinssikaupungissa kirjoittava nainen oli tuplasti toiseutettu. Savkinan tavoin Lounsbery käsittelee provinssikirjailijoista Jelena Gania ja Marija Žukovaa, mutta hänen käsittelynsä ulottuu myös 1800-luvun jälkimmäiselle puoliskolle ja Nadežda Hvoštšinskajaan asti.

Lounsbery on taitava kirjoittaja, joka osaa lukijaystävällisessä tekstissään yhdistää teoreettisen ja analyyttisen otteen. Lukija huomaa pian innostuvansa ja uppoutuvansa dialogiin kirjoittajan ja tämän käsittelemien kirjailijoiden kanssa. Kun kyse on mittavan klassikkokirjailijamäärän käsittelystä, ei kaikkien analyysien syvyys ja erittelevyys tunnu riittävältä, vaan tekijä on myös joutunut vetämään mutkia suoriksi. Teosta olisi kenties palvellut esimerkiksi aiemmin mainitun Dobytšinin kaltaisten vähemmän tutkittujen kirjailijoiden tarkempi analyysi ja nyt melko yllätyksettömästi lähestyttyjen kirjailijoiden, kuten Tšehovin, jättäminen suosiolla vähemmälle huomiolle. Kattavaan kokonaisesitykseen pyrkivässä teoksessa nykyiset ratkaisut toki perustelevat itsensä.

Kokonaisuutena Anne Lounsberyn Life is Elsewhere on merkittävä teos, joka tarjoaa paljon löytämisen ja tunnistamisen iloa 1800-luvun kirjallisuuden ystäville sekä provinssikirjallisuuden tutkijoille ylipäätään.

Tintti Klapuri ja Anni Lappela 